\title{
Patrioci krytyczni kontra mitomani. Walka o politykę historyczna w obliczu Grossa
}

Datriotyzm wydaje się być jednym z tych pojęć, których nie sposób jasno i wyraźnie zdefiniować. Nie ma jednego, powszechnie obowiązującego wzorca, choć może niektórzy usilnie próbują go ustalić. Jego granice są rozmyte, dlatego przez różnych ludzi bywa różnie odczytywany, wypełniany odmiennymi treściami, a niejednokrotnie - nadinterpretowany. Zauważyć można przynajmniej dwa, wzajemnie się wykluczające, modele - patriotyzm „krytyczny”, zwracający uwagę na całokształt doświadczeń narodu, w tym niechlubnych, i ten „konserwatywny”, idealistycznie zauważający tylko to, co w polskości piękne, dobre i dumne bądź wzniosłe, pełne poświęcenia i cierpienia - niebezpiecznie bliski nacjonalizmowi. „Niepokoi mnie to, że polskie pojmowanie nacjonalizmu czyni zeń fenomen peryferyjny, podczas gdy w rzeczywistości chodzi o sposób myślenia i odczuwania o niezwykle szerokim zasięgu” - pisał Jerzy Szacki, dodając: „Siła uczuć narodowych jest wprawdzie zmienna w czasie i ogromnie zróżnicowana w przestrzeni, ale nic nie wskazuje na to, byśmy mieli gdziekolwiek do czynienia z wyraźną tendencją zniżkową".

Tak różne sposoby jego postrzegania bardzo wyraziście opisywał już Jan Józef Lipski w słynnym eseju Dwie ojczyzny - dwa patriotyzmy. Uwagi o megalomanii narodowej i ksenofobii Polaków, powstałym w 1981 roku. Swoją definicję ojczyzny i patriotyzmu buduje jako opozycję w stosunku do obcych, stawiając fundamentalne pytanie - czy uważamy się tylko za innych czy za lepszych od owych „obcych”. Mogą być nimi Niemcy, Rosjanie czy inni wschodni sąsiedzi, mogą być Żydzi, może być i kultura Zachodu. Jako składnik tego „prawdziwego” patriotyzmu, podaje między innymi uznanie także tych haniebnych, ciemnych kart historii, podkreślając, że „każde przemilczenie staje się oliwą do ognia megalomanii narodowej, jest chorobą; każde uchylenie się od uznania własnych win - jest niszczeniem etosu narodowego" ${ }^{2}$.

${ }^{1}$ J. Szacki, O narodzie i nacjonalizmie, „Znak” 1997, nr 3, s. 4-31.

${ }^{2}$ J. J. Lipski, Dwie ojczyzny - dwa patriotyzmy [w:] Ile ojczyzn? Ile patrioty- 
Mimo że definiuje te kluczowe pojęcia przez pryzmat „obcych”, to tak naprawdę najważniejszy i zarazem najciekawszy jest stosunek Polaków do samych siebie - własnej tradycji, historii, dokonań, zwycięstw i porażek. Autor podkreśla przecież, że z ksenofobią idzie w parze megalomania narodowa, przypominając choćby romantyczny mesjanizm, zwracając uwagę także na liczne przypadki „ojczyźniano patriotycznej frazeologii”, również we współczesnej jemu rzeczywistości. J. J. Lipski wie, że dla wielu czytelników jego spostrzeżenia będą nie do przyjęcia. A będzie to oznaką właśnie szeroko rozpowszechnionego w społeczeństwie fałszywego oblicza patriotyzmu, pod którym w rzeczywistości skrywają się ksenofobia i megalomania - nazwane po imieniu już w tytule jego słynnego eseju.

J. J. Lipski zarysowuje więc obraz dwóch skrajnie różnych stosunków do pojęć ojczyzny i patriotyzmu. Jego podział na patriotów i megalomanów znajduje odbicie także w późniejszych publikacjach. Taki sposób rozumowania zdaje się bowiem bardzo trafnie diagnozować również problemy bliższej nam czasowo rzeczywistości, a w szczególności sytuację na arenie politycznej po 2005 roku, kiedy to po wyborach parlamentarnych główną rolę odgrywało Prawo i Sprawiedliwość. Zwycięstwo tej partii i, co za tym idzie, propagowanie specyficznej prawicowej polityki historycznej dało asumpt do opublikowania w 2007 roku zbioru esejów Ile ojczyzn? Ile patriotyzmów?, oscylujących tematycznie wokół wspomnianego tekstu J. J. Lipskiego, a będących odpowiedzią środowiska lewicowego na działania PiS. W esejach Rafała Chwedoruka, Macieja Gduli, Adama Ostolskiego, Marcina Starnawskiego, Pawła Rudnickiego, Bartosza Machalicy, Michała Syski, Stefana Zgliszczyńskiego oraz Sławomira Sierakowskiego przewija się głównie wątek wszechogarniającej polityki historycznej promowanej przez skrajną prawicę i nieumiejętności wytworzenia przez lewicę jasnej i spójnej odpowiedzi na nią. Według autorów opracowania mamy tu do czynienia nie tyle z konfliktem odmiennych pamięci historycznych, ale z jedną, oficjalną i odgórnie narzuconą wykładnią historii, co przywołuje skojarzenia raczej z kształtem konfliktu w społeczeństwie niedemokratycznym, niż z normalnymi stosunkami w demokratycznym państwie. S. Zgliszczyński w artykule Państwo $F$. pisze nawet, że „wygranie wyborów prezydenckich i parlamentarnych przez Prawo i Sprawiedliwość oraz utworzenie przez nią rządu ze skrajną prawicą postawiło na porządku dziennym pytanie czy Polakom przyjdzie

zmów?, red. M. Syska, Warszawa 2007, s. 11. 
zmagać się z kolejną - po neoliberalizmie - plagą, mianowicie plagą faszyzacji życia publicznego"3. Odpowiedź wyłaniająca się z lektury tego eseju jest - nietrudno odgadnąc - twierdząca. Ten sam autor, biorąc pod uwagę nie tylko oktrojowaną politykę historyczną, ale całokształt działań PiS u sterów władzy, nazywa zresztą IV RP kpiną z demokracji ${ }^{4}$. Najwięcej uwagi twórcy poświęcają jednak właśnie wypaczonej polityce historycznej, która jesienią 2005 roku stała się jednym z głównych haseł podnoszonych przez rządzącą partię.

Warto poświęcić osobne miejsce samemu pojęciu polityki historycznej (czy też polityki pamięci, będącej niejako narzędziem w rękach patriotów-konserwatystów), które, choć tak chętnie używane, jest niejednoznaczne, umowne, o szerokim zakresie. Autorzy Ile ojczyzn?... sięgają do historycznej genezy polityki pamięci polskiej prawicy (R. Chwedoruk w artykule Trzy ojczyzny, trzy patriotyzmy. Polityka historyczna a doświadczenie polskiej lewicy przywołuje tradycję niepodległościowo-piłsudczykowską, dmowszczyznę czy konserwatywny liberalizm), jak i lewicowych źródeł. U R. Chwedoruka jej lewicowe korzenie zapuszczone są gdzieś między socjaldemokratycznym postmarksizmem, post-PRL-owską tradycją, a całkowitym zaprzeczeniem jakiejkolwiek polityki pamięci, ahistoryzmem, bo czy historię można kształtować tak samo jak inne dziedziny życia? M. Gdula w tekście $P a-$ mięć $i$ lewica o lewicowym postrzeganiu polityki pamięci pisze jeszcze ogólniej - jako o domenie historyków, do której nie należy się wtrącać, a z drugiej strony pamięć o niedalekiej przeszłości odbierana jest jako ta, która „jest po stronie lewicy i nic już tego nie zmieni”, obie opcje, ukazując jako niewystarczające do ukształtowania własnej odpowiedzi na prawicową politykę pamięci. Bez wątpienia, pojęcie polityki historycznej utożsamiane jest zdecydowanie z prawicą. Czym więc ona jest w prawicowej wizji? Jak mówił Robert Traba w wywiadzie dla „Gazety Wyborczej”: „polityka historyczna, która weszła przebojem do dyskursu publicznego, jest enigmą. Nikt nie wie, co to jest i na czym miałoby polegać. W odpowiedziach orędowników polityki historycznej znalazłem natomiast kilka elementów, które ją określają, choć nie definiują. Po pierwsze, chodzi o afirmację historii narodowej. Po drugie, polityka historyczna budowana jest w opozycji do tradycji patriotyzmu krytycznego. I po trzecie, ma ją kreować państwo, czyli rząd. Każdy

\footnotetext{
${ }^{3}$ S. Zgliszczyński, Państwo F., [w:] Ile ojczyzn?..., op. cit., s. 117-118.

4 Ibidem, s. 125.

${ }^{5}$ M. Gdula, Pamięć i lewica, [w:] Ile ojczyzn?..., op. cit., s. 68.
} 
z tych punktów budzi obawy”. Według R. Traby, „polityka historyczna to praca na dziesięciolecia, a nie na jedną kadencję rządu, Sejmu czy prezydenta" 7 . Nie powinna być więc doraźnym działaniem, upodobaniem rządzącej partii. A przede wszystkim, co podkreśla także Lech Nijakowski, „polityka pamięci nie może być megalomańska, ani synonimem propagandowego samochwalstwa"8. Pojęcie to zapożyczono z języka niemieckiego, w którym „Geschichtpolitik” było odpowiedzią na pozostałości nazizmu. Celem polityki historycznej było popularyzowanie indywidualizmu, otwartości, tolerancji czy krytycznego stosunku do dziedzictwa narodowego ${ }^{9}$. W Polsce zdaje się być zgoła inaczej - prawicowi promotorzy polityki historycznej uczynili ją raczej odpowiedzią na indywidualizm, na kwestionowanie obrazu Polski jako państwa bohaterów i cierpiących. Polska polityka historyczna umacniać ma wspólnotę narodową, ma popularyzować poczucie dumy z dokonań przodków ${ }^{10}$. Równocześnie trudno mówić o jakiejś spójnej strategii jej prowadzenia, choć autorzy zbioru Ile ojczyzn?... zauważają jej wszechobecność w mediach, a nawet w systemie szkolnictwa (problem ten dogłębnie analizuje P. Rudnicki w tekście Edukacja mamiaca: obywatel - szkoła - władza. W matni heteronomicznej rzeczywistości).

Barbara Szacka posługuje się pojęciem „mitologizacji przeszłości w pamięci zbiorowej”, które zdaje się być w odniesieniu do polskiego przypadku bardzo adekwatne i przez wielu autorów - począwszy od J. J. Lipskiego - chętnie podkreślane, choć może nie dosłownie. Według B. Szackiej, pamięć zbiorowa (a takiej właśnie, nie jednostkowej dotyczy oczywiście polityka historyczna) obejmuje także treści profaniczne, a mit związany jest nieodłącznie ze sferą sacrum ${ }^{11}$. W kontekście państwowej polityki pamięci największym problemem nie jest więc wzmocnienie przy jej użyciu władzy rządzących, ale właśnie selektywność i mitologizacja tej pamięci. Przeszłość, która mówi o bo-

${ }^{6}$ J. Kurski, Kicz patriotyczny, „Gazeta Wyborcza” z dnia 6 stycznia 2006 roku, wywiad ukazał się także w książce Roberta Traby Historia - przestrzeń dialogu, Warszawa 2006, s. 9-10.

7 Ibidem, s. 19.

${ }^{8}$ L. Nijakowski, Polska polityka pamięci, Warszawa 2008, s. 257.

${ }^{9}$ Więcej na temat niemieckiego kontekstu polityki historycznej: A. Wolff-Powęska, Polskie spory o historię i pamięć, „Przegląd Zachodni”, 2007, nr 1.

${ }^{10} \mathrm{O}$ przeniesieniu pojęcia na grunt polski szerzej pisze A. Smolar, Wtadza i geografia pamięci, [w:] Pamięć. Wyzwanie dla nowoczesnej Europy, red. R. Traba, Olsztyn 2008, s. 51-63.

${ }^{11}$ B. Szacka, Czas przeszły, pamięć, mit, Warszawa 2006, s. 92-95. 
haterstwie lub cierpieniu Polaków jest sakralizowana, zaś niechciane dziedzictwo - odrzucane w niepamięć. Taką tendencję do idealizowania wspólnej przeszłości zaobserwował już J. J. Lipski, ostrzegając: „jestem przekonany, że jednym z najistotniejszych zagadnień naszej teraźniejszości i przyszłości jest wyzbycie się megalomanii narodowej i ksenofobii, a przynajmniej ich stępienie do stanu niegroźnego dla dalszych losów narodu polskiego"12.

W dyskusji nad pamięcią jako wyzwaniem dla Europy Gesine Schwan zauważa, że problem mitologizacji przeszłości i związanego z tym wypaczonego pojmowania patriotyzmu nie jest wyłącznie domeną Polaków. Zwraca uwagę na to, że dowartościowywanie się poprzez identyfikację z bohaterskimi czynami jest prostym i powszechnym mechanizmem psychologicznym, spontaniczną tendencją pamięci różnych narodów. Dostrzega jednak fakt, iż jest to zbyt prosta droga do wzmacniania świadomości wspólnoty. Jej zdaniem, można i należy znaleźć w Europie pozytywną wspólną kulturę pamięci, w której czarne plamy historii nie będą negowane. Wspólną bazę europejskich wartości można bowiem wytworzyć tylko wtedy, gdy i ciemną stronę historii przyjmie się do świadomości i zrozumie, że epizody te miały miejsce, ale były złe, niszczyły Europę ${ }^{13}$. Także S. Sierakowski w tekście W Polsce, czyli wszędzie ze zbioru Ile ojczyzn?... stara się ukazać niektóre obecne na polskim gruncie zjawiska jako uniwersalne. W tytule odwołuje się do sztuki Alfreda Jarry'ego Ubu król czyli Polacy, niegdyś budzącej ogromne emocje i odbieranej jako paszkwil wycelowany w Polskę i Polaków. Populistyczny Ubu zdobył władzę w Polsce, czyli nigdzie - jak twierdził autor sztuki po premierze w 1896 roku, tam też tropił spiski, atakując to elity, to sąsiadów. S. Sierakowski silnie odwołując się do Chantal Mouffe (pozostaje pod wpływem jej koncepcji postpolityki, radykalizacji demokracji, „spychania” pluralizmu do sfery prywatnej) zapewnia, że nie dzieje się to nigdzie, ale wszędzie. Przecież nie tylko na naszym podwórku, ale także w innych państwach uwidacznia się populizm, który, jak pisze, jest naturalnym etapem rozwoju liberalnej demokracji, wszędzie dochodzi także do zaniku widocznych różnic między prawicą a lewicą (czy nawet konsensusu w centrum, co zauważała Ch. Mouffe). S. Sierakowski, jak i pozostali autorzy Ile ojczyzn?... mają jednak raczej pesymistyczne poglądy co

${ }^{12}$ J. J. Lipski, Dwie ojczyzny - dwa patriotyzmy, [w:] Ile ojczyzn?..., op. cit., s. 35.

${ }^{13}$ Fragment debaty Wspólna Europa, wspólna historia? z udziałem Gesine Schwan, Marca Noushi, Roberta Traby i Adama Michnika, opublikowanej w książce Pamięć..., op. cit., s. 30 . 
do stworzenia wspólnej, uniwersalnej tożsamości Polaków i innych narodów, ukazując to co ponadnarodowe, globalne, jako zagrożenie tożsamości narodowej z punktu widzenia zwolenników i propagatorów polskiej polityki historycznej (między innymi M. Starnawski w artykule Naród, ojczyzna, tożsamość: o iluzjach urzeczywistnionych pokazuje, jak w ucieczce od globalizacji do pojęcia narodu łatwo otrzeć się o nacjonalizm).

Zaproponowany przez J. J. Lipskiego (co najmniej) dychotomiczny podział ludzi, ze względu na prezentowany stosunek wobec narodowej historii inspirował nie tylko twórców powyższego zbioru. Według Michała Bilewicza istnieją obok siebie dwie Polski - Polska „krytycznych patriotów" i Polska ludzi wierzących w nieskalany i wyidealizowany wizerunek własnego narodu ${ }^{14}$. Sławomir Sierakowski także w innych publikacjach nazywa ich „światłymi obywatelami” i „upokorzonymi patriotami”"15, a L. Nijakowski proponuje przyporządkowanie im modelów polityki pamięci - odpowiednio rewizjonistyczno-krytycznego i konserwatywnego ${ }^{16}$. Wydaje się, że walka między patriotami i mitomanami trwała niemalże od zawsze, dlatego też żaden $\mathrm{z}$ autorów nie pokusił się o wyznaczenie jej początkowych granic, byłoby to zresztą chyba niemożliwe. J. J. Lipski jednak prognozuje, a inni autorzy dostrzegają jej nasilenie - w związku z „ofensywą martyrologiczną IV RP”17. Mimo tak jednoznacznego wskazania „winnych”, autorzy Ile ojczyzn?... zdają sobie sprawę z tego, że problem nie zniknie wraz z końcem rządów PiS, wskazując na znacznie głębsze jego podłoże. Dowodem na silne zakorzenienie megalomańskich poglądów w polskim społeczeństwie są choćby niegasnące spory wokół kolejnych książek Jana Tomasza Grossa.

R. Traba, odwołując się do debaty wywołanej publikacjami Grossa, szczególnie pierwszej tak głośnej z nurtu „rozliczeniowego”, Strach. Antysemityzm $w$ Polsce tuż po wojnie: historia moralnej zapaści, mówi o „narodowej »traumie Jedwabnego«, która zachwiała fundamentalnym mitem Polaka postrzeganego jedynie jako bohater i ofia-

${ }^{14}$ M. Bilewicz, Nie tylko o „Strachu”. Psychologia potocznego rozumienia historii, „Zagłada Żydów. Studia i materiały” 2008, nr 4, s. 522-523.

15 S. Sierakowski, Chcemy innej historii, „Gazeta Wyborcza” z dnia 11 czerwca 2003 r., s. 15.

${ }^{16}$ L. Nijakowski proponuje także trzeci, pośredni, liberalno-konserwatywny model. Szerzej w rozdziale Jaka polityka pamięci? [w:] L. Nijakowski, Polska polityka pamięci, Warszawa 2008, s. 242-244.

${ }^{17}$ Określenie propagowanej przez PiS polityki historycznej, używane przez Lecha Nijakowskiego w książce Polska..., op. cit. 
ra i ukazała go również w roli sprawcy. To doświadczenie wywołało wstrząs i tęsknotę za pierwotnym mitem martyrologicznym, na którym budowaliśmy od zawsze naszą tożsamość narodową"18 - stwierdza. Podobnie Sąiedzi. Historia zagłady żydowskiego miasteczka J. T. Grossa, choć to nie pierwsza publikacja dotyczącą stosunku Polaków wobec Zagłady ${ }^{19}$ Żydów, to właśnie ona wywołała burzliwą dyskusję, która pozwoliła zaistnieć jedwabieńskiej historii w zbiorowej świadomości. J. T. Gross ukazywał w niej bowiem nie obojętność, o której pisał wcześniej choćby Jan Błoński w eseju Biedni Polacy patrzą na getto $^{20}$, ale uczestnictwo Polaków w Zagładzie - w roli sprawców. Jak pisze Piotr Forecki, który analizował debatę publiczną „po Grossie”, „ujawnienie przez Jana Tomasza Grossa szokującej jedwabieńskiej zbrodni uznano za zderzenie Polaków z ich własną trudną przeszłością, dotychczas spowitą milczeniem i odrzucaną. Jedwabne w sposób dosłowny i symboliczny traktowano jako wyzwanie ujrzenia narodowej przeszłości w jej pełnym i złożonym wymiarze. Jako nakaz wzbogacenia perspektywy poznawczej o te postawy Polaków względem Żydów, które nie stanowią powodu do dumy, lecz hańbią, a zwłaszcza do zobaczenia siebie w nowej roli: nie ofiar, ale sprawców czyjegoś nieszczęścia”"21. Debata ta była o tyle cenna, że J. T. Gross zadał w Sąsiadach kluczowe dla pojęcia polityki historycznej pytanie - czy „nie jesteśmy również odpowiedzialni za dokonania haniebne przodków i współziomków? Innymi słowy, czy możemy sobie z toku dziejów dowolnie wybierać schedę, do której się poczuwamy, ogłaszając, że »to jest Polska właśnie«?”22. Według R. Traby, to właśnie w dyskursie wywołanym przez publikacje J. T. Grossa najwyraźniej uwidoczniła się polityka historyczna. $Z$ jednej strony sprzyjała więc rozbudzeniu się patriotyzmu „konserwatywnego”, z drugiej była bez wątpienia potrzebną „terapią szokową”. Jak odnotował P. Forecki, w toku debaty, toczącej się niemal dwa lata od publikacji Sąsiadów, padały takie

${ }^{18}$ Wywiad Jarosława Kurskiego z Robertem Trabą, [w:] Historia - przestrzeń dialogu, op. cit., s. 10-11, 15-16.

${ }^{19}$ Termin Zagłada pisany wielką literą jest tu synonimem terminów Shoah oraz Holocaust, oznaczających zagładę Żydów podczas II wojny światowej. Por. M. Adamczyk-Garbowska, H. Duda, Terminy Holokaust, Zagłada i Szoa oraz ich konotacje leksykalno - kulturowe w polszczyźnie potocznej i dyskursie naukowym, [w:] Żydzi i judaizm we wspótczesnych badaniach polskich, red. K. Pilarczyk, t. 3, Kraków 2003, s. 237-253.

${ }^{20}$ J. Błoński, Biedni Polacy patrzą na getto, „Tygodnik Powszechny” 1987, nr 2.

${ }^{21}$ P. Forecki, Spór o Jedwabne. Analiza debaty publicznej, Poznań 2008, s. 66.

${ }^{22}$ J. T. Gross, Sąiedzi. Historia zagłady żydowskiego miasteczka, Sejny 2000, s. $97-98$. 
określenia jak „narodowa terapia”, „katharsis”, „najważniejszy egzamin, przed jakim stanęliśmy jako Polacy w ostatnim dziesięcioleciu”, „poligon do ćwiczeń nad polską mentalnością”, „pierwsza po 55 latach próba spojrzenia w lustro” czy „probierz polskich dusz i charakterów, wielki konfesjonał i zbiorowa kozetka psychoanalityka"23.

W dyskusji z okazji 6o. rocznicy pogromu kieleckiego, opublikowanej w lipcu 2006 roku na łamach magazynu „Charaktery”, Mirosław Kofta wypowiadał się dość powściągliwie na temat zmian społecznych spowodowanych debatą o polskich zbrodniach dokonywanych na Żydach. W jego opinii, wola niepamięci społeczeństwa polskiego jest nadal bardzo silna. „Mam wrażenie, że w Polsce jeszcze nie osiągnęliśmy takiego poziomu publicznego dyskursu, na którym moglibyśmy oswoić się z trudną prawdą, że jakaś część Polaków również uczestniczyła w eksterminacji Żydów" - stwierdził. Winy doszukiwał się w systemie komunistycznym, w którym badania historyczne, jeśli już udało się takie przeprowadzić, nie mogły oglądać światła dziennego, a więc społeczeństwo żyło w przekonaniu, że nic strasznego się nie działo. Zauważył jednak, że również po 1989 roku fakty te z trudem docierają do świadomości Polaków, co jest według niego związane $\mathrm{z}$ istnieniem silnych barier psychologicznych, które nazwał „kolektywną tożsamością publiczną". Chodziło mu o wyidealizowaną koncepcję Polaków jako ludzi z natury dobrych, szlachetnych tolerancyjnych - i nie tylko w myśleniu samych Polaków o sobie, ale również w takim ich postrzeganiu przez inne narody, a w tej dziedzinie jesteśmy według niego narodem nadwrażliwym ${ }^{24}$. W tej samej debacie M. Bilewicz odpowiadał, że z badań wynika, iż Polacy postrzegają samych siebie bardzo negatywnie i starają się jakoś to zrekompensować, budując obraz Polaków jako tych lepszych moralnie, którzy nigdy nie zrobili nic złego, a ich przeszłość to historia chwały.

Czegokolwiek by nie powiedzieć o publicznej debacie wywołanej kolejnymi publikacjami J. T. Grossa, jest ona niemałym fenomenem. Jego książki, w przeciwieństwie do wielu poważnych publikacji cenionych historyków, sprzedawane są w nieporównywalnie większych nakładach. Jak pisze w „Charakterach” Adrian Wójcik, „Strach Jana Tomasza Grossa rozpętał w Polsce prawdziwą medialną burzę. O Strachu dyskutują wszyscy - i ci, co są „za”, i ci, co są „przeciw”. Szcze-

${ }^{23}$ Zob.: P. Forecki, Spór o Jedwabne..., op. cit., s. 58.

${ }^{24}$ A jak bratem, a jak katem, dyskusja w 6o. rocznicę pogromu kieleckiego z udziałem B. Weigl, M. Kofty, S. Kapralskiego, A. Żbikowskiego, M. Bilewicza i B. Białka, „Charaktery" 2006, $\mathrm{nr}$ 7, s. 74-82. 
gólnie silnie brzmią głosy krytyczne podszyte strachem przed najnowszą książką Grossa. Czego boją się krytycy? Można odnieść wrażenie, że kryje się za tym przede wszystkim obawa, że Strach stanie się jedyną książką historyczną dotyczącą tamtych wydarzeń, którą miał w ręku czytelnik" 25. Zaznacza, że krytycyzm wobec J. T. Grossa zasadza się przede wszystkim na przekonaniu o niskiej świadomości historycznej odbiorców. Optymiści widzą wielką rolę tego autora w sprowokowaniu ogólnonarodowej debaty, która, być może, wyrobi w społeczeństwie nawyk sięgania po inne pozycje dotyczące tej tematyki - choćby dla zweryfikowania kontrowersyjnych treści.

Wydaje się, że właśnie kontrowersja jest największym zarzutem wobec tego autora, jak i - paradoksalnie - jego największą siłą. Gorące dyskusje i zażarte spory rozpoczynają się jeszcze przed wydaniem każdej kolejnej książki, głos w dyskusji zabierają nawet ci, którzy publikacji nie przeczytali, ale opinię już zdążyli sobie wyrobić. Tak jest i w przypadku najnowszej publikacji Ztote żniwa. Rzecz o tym, co się działo na obrzeżach zagłady Żydów J. T. Grossa i Ireny Grudzińskiej-Gross, która pojawiła się drukiem w marcu tego roku. Tym razem opowiada o grabieżach Polaków na pomordowanych Żydach, w centralnym punkcie rozważań stawiając fotografię ludzi uczestniczących w „wykopkach” w Treblince. Zaznacza jednak, że grabieże były ściśle powiązane z mordem, bo, jak pisze, „Polityka Zagłady (a także usiłowanie wymordowania przez ludność miejscową, tak jak w Jedwabnem czy Radziłowie, wszystkich żydowskich sąsiadów) w perspektywie zaboru mienia ma i tę logikę, że dopóki potomstwo ofiar albo jacyś krewni pozostają przy życiu, dopóty przejęcie żydowskiej własności jest odwracalne. Całkowite wykorzystanie Żydów i ich majątku spełnia się dopiero wraz ze śmiercią ich wszystkich" ${ }^{26}$. Fragmenty tej książki publikuje na swej stronie internetowej ksiądz Tadeusz Isakowicz-Zaleski, komentując „Moja recenzja jest krótka - grafomaństwo i skrajne naginanie faktów. Jednym słowem, obrzydliwość” ${ }^{27}$, niemal dwa miesiące przed publikacją, bo 3 stycznia, Tomasz Lis poświęca książce cały swój program „Tomasz Lis na żywo”, dyrektor wydawnictwa „Znak”, Danuta Skóra, przeprasza za publikację Złotych żniw... O J. T. Gros-

${ }^{25}$ A. Wójcik, Dyskusja Strachem podszyta, „Charaktery”, 2008, nr 4, s. 94-97.

${ }^{26} \mathrm{~J}$. T. Gross, I. Grudzińska-Gross, Złote żniwa. Rzecz o tym, co się działo na obrzeżach zagłady Żydów, Kraków 2011, s. 113.

${ }^{27}$ Wpis na blogu ks. T. Isakowicza-Zaleskiego z 1 lutego 2011 r., Maszynopis Grossa krąży po Krakowie, http://www.isakowicz.pl/index.php?page=news\&ki$\mathrm{d}=8 \&$ nid $=374814.03 .2011 \mathrm{r}$. 
sie znów jest głośno, choć coraz częściej pojawiają się pytania już nie o prawdziwość przedstawianych zdarzeń, ale o rzetelność jego pracy badawczej. Zarzuca mu się stosowanie nieodpowiednich, nieprzystojących historykowi metod badawczych, wskazuje się na zbytnie uogólnienia. Równocześnie jednak podkreśla się, że jako pierwszy przełamuje tabu haniebnej przeszłości i odważnie odkrywa czarne karty historii Polaków. Na pierwszy ogień nie idą więc dawne zarzuty o brak miłości do ojczyzny i szerzenie kłamstwa, co znaczyłoby chyba, że po kolejnym wstrząsie także czarne karty historii dochodzą do społecznej świadomości. Czy wróży to sukces patriotów „krytycznych”?

Emocje, jakie wzbudzają kolejne publikacje J. T. Grossa mogą świadczyć o tym, że prezentowana przez PiS polityka historyczna jest silnie zakorzeniona w społeczeństwie, ale może jej podłoże tkwi jeszcze głębiej niż w postulatach Prawa i Sprawiedliwości? Z pewnością związani z tym ugrupowaniem politycy czy publicyści podsycają spór, co widoczne jest także w debacie publicznej wokół publikacji J. T. Grossa. Jest ona znakomitym zwierciadłem, wyraźnie ukazującym przeciwne w sporze o politykę historyczną obozy. Można jednak odnieść wrażenie, że linia podziału między patriotami „krytycznymi” i „mitomanami” nie jest tak łatwa do zarysowania, jak mogłoby się wydawać, a sama tradycja prawicowości czy lewicowości chyba nie jest tu dostatecznym rozróżnieniem. Steru władzy nie dzierży już PiS, a mimo to dla wielu właściwą postawą nadal nie jest krytyczny patriotyzm, ale ten mitologizujący heroiczną przeszłość, choć z pewnością Strach, Sasiedzi czy Złote żniwa łamią pewne bariery. Czy jednak megalomania nie jest może zakorzeniona znacznie głębiej, niezależnie od czasów i ponad podziałami politycznymi?

Jak podkreśla B. Szacka, przekształcenia obrazu przeszłości (choćby takie jak jej mitologizowanie), zachodzą nieustannie, ale towarzyszą w szczególności wszelkim głębokim przemianom społecznym czy ustrojowym $^{28}$. Według autorki, do najważniejszych funkcji pamięci zbiorowej należy funkcja tożsamościowa. Wielu autorów zaznacza, że zmiany zachodzące we współczesnym świecie powodują często poczucie wykorzenienia, dezorientacji tożsamościowej i niepewności przyszłości, a więc podstawowe funkcje pamięci zbiorowej zawodzą ${ }^{29}$. Być może to właśnie dlatego na jej gruncie dochodzi do nieraz do „naginania" historii, koloryzowania i sakralizowania przeszłości - by dowar-

\footnotetext{
${ }^{28}$ B. Szacka, Czas...,op. cit., s. 206.

${ }^{29}$ Ibidem, s. 46-66.
} 
tościować się, podbudować zanikające korzenie silnym fundamentem wartości, nawet wyolbrzymionych czy wręcz wykreowanych. Nie można jednak zapominać o innej, równie istotnej funkcji pamięci zbiorowej - legitymizacji - nie tylko samego faktu istnienia danej zbiorowości, ale i form władzy politycznej ${ }^{30}$. Jej przedstawiciele doskonale zdają sobie sprawę z wagi pamięci dla istnienia każdego porządku politycznego, a mając uprzywilejowaną pozycję w jej przekazywaniu „coraz więcej państw prowadzi mniej lub bardziej świadomą politykę historyczną, wspierając swoim autorytetem i środkami materialnymi konkretne interpretacje historii" ${ }^{1}$.

\section{SUMMARY}

PAtriotism is one of the concepts that cannot be easily interpreted. It can be seen at least two models of patriotism - „critical”, which draws attention also to the shameful experience and „conservative”, associated with the myth of proud and suffering of the Polish nation, connected also with a specific historical policy. Visible manifestation of these extreme camps are public debates on the publications of J. T. Gross, showing the Poles as perpetrators of suffering and death of many Jews.

\section{NOTA O AUTORCE}

Agnieszka Misiewicz [agnieszka.maria.misiewicz@gmail.com] studentka I roku politologii studiów II stopnia na Wydziale Nauk Politycznych i Dziennikarstwa. Interesuje się związkami polityki z innymi dziedzinami życia i nauki - kulturą (szczególnie teatrem), historią (polityka pamięci), socjologią czy psychologią.

${ }^{30}$ Ibidem, s. 54 .

${ }^{31}$ D. Gawin, O pożytkach i szkodliwości historycznego rewizjonizmu, „Przegląd Polityczny" 2006, nr 75, s. 34. 
